The Journal of African History

http://journals.cambridge.org/AFH

Additional services for The Journal of African History:

Email alerts: $\underline{\text { Click here }}$

Subscriptions: Click here

Commercial reprints: Click here

Terms of use : $\underline{\text { Click here }}$

\title{
'CHANGING TRADITIONS TO MEET CURRENT ALTERING CONDITIONS': CUSTOMARY LAW, AFRICAN COURTS AND THE REJECTION OF CODIFICATION IN KENYA, 1930-60
}

\author{
BRETT L. SHADLE \\ The Journal of African History / Volume 40 / Issue 03 / November 1999, pp 411 - 431 \\ DOI: null, Published online: 08 September 2000
}

Link to this article: http://journals.cambridge.org/abstract_S0021853799007513

How to cite this article:

BRETT L. SHADLE (1999). 'CHANGING TRADITIONS TO MEET CURRENT ALTERING CONDITIONS': CUSTOMARY LAW, AFRICAN COURTS AND THE REJECTION OF CODIFICATION IN KENYA, 1930-60. The Journal of African History, 40, pp $411-431$

Request Permissions : $\underline{\text { Click here }}$

Copyright Cambridge University Press. BRETT L. SHADLE (1999). 'CHANGING TRADITIONS TO MEET CURRENT ALTERING CONDITIONS': CUSTOMARY LAW, AFRICAN COURTS AND THE REJECTION OF CODIFICATION IN KENYA, 1930-60. The Journal of African History, 40, pp 411-431. 
Fournal of African History, 40 (I999), pp. 4I I-43I. Printed in the United Kingdom

(C) 1999 Cambridge University Press

\title{
'CHANGING TRADITIONS TO MEET CURRENT ALTERING CONDITIONS': CUSTOMARY LAW, AFRICAN COURTS AND THE REJECTION OF CODIFICATION IN KENYA, 1930-60*
}

\author{
BY BRETT L. SHADLE \\ Northwestern University
}

If the aim of British colonizers, Frederick Lugard wrote, was to civilize Africans 'and to devote thought to those matters which... most intimately affect their daily life and happiness, there are few of greater importance than the constitution of native courts'. Moreover, he argued that only from native courts employing customary law was it 'possible to create rudiments of law and order, to inculcate a sense of responsibility, and evolve among a primitive community some sense of discipline and respect for authority'. ${ }^{1}$ Britain had not the manpower, the money nor the mettle to rule by force of arms alone. Essentially, in order to make colonial rule work with only a 'thin white line' of European administrators, African ideas of custom and of law had to be incorporated into the new state systems. ${ }^{2}$ In a very real way, customary law and African courts provided the ideological and financial underpinnings for European colonial rule.

In Kenya from at least the I920s, but especially in the I940s and I950s, administrators struggled with the question of how customary law could best be used in African courts. Prominent among their concerns was the codification of customary law, against which most administrators vigorously fought. ${ }^{3}$ British officials believed that reducing African custom to written law

* The research on which this paper is based was funded by an NSEP I 997-8 fellowship (funding research in Kenya) and a Northwestern University Dissertation Year Grant (funding research in Great Britain). I wish to thank the Office of the President, Government of Kenya, for authorizing my research and the Department of History at the University of Nairobi for my affiliation there. My thanks also to Jonathon Glassman, Rebecca Sheriekis, members of the History Department Brown Bag Seminar at Northwestern University, and the anonymous $\mathcal{F} A H$ reviewers for their comments on earlier versions of this paper.

1 Lord Lugard, The Dual Mandate in British Tropical Africa (London, I965 [1922]), $547^{-8}, 549^{-}{ }^{\circ}$.

2 See Karen Fields, Revival and Rebellion in Colonial Central Africa (Portsmouth, NH, I 997), chs. I-2.

3 This may well have been true for other periods as well, though documentation is slim. In I 923, the Chief Native Commissioner (CNC) defended the Native Tribunals from an attack by the Chief Justice of the Supreme Court. 'I am opposed', the CNC wrote, 'to anything in the nature of codification of native law for many years to come, it is the boast of our own system that it is elastic...' CNC to Acting Colonial Secretary, 27 July I 923, Kenya National Archives (KNA) (Nairobi): Jud I/ I I04. Most of the KNA files used in this paper are those dealing directly with African court matters, and in particular papers and correspondence from the office of the Judicial Advisor (JA, later known as Native Courts Officer $[\mathrm{NCO}]$ and African Courts Officer [ACO]). These files provide a rich source of information for administrative ideas about African law and society and how these ideas informed policies for African courts. 
and placing it in a code would 'crystalize' it, altering its fundamentally fluid or evolutionary nature. ${ }^{4}$ Colonizers naturally harbored intentions of using the law to shape society (as Cooper has demonstrated for the Kenya coast $t^{5}$ ) but a fluid, unwritten law provided much greater latitude to pursue these goals. It was necessary, as one administrator put it, to allow 'changing traditions to meet current altering conditions'. ${ }^{6}$

This case study of Kenya offers a different understanding of the history of customary law. Scholars have sought to examine exactly how colonial administrators used customary law to legitimize the colonial state and mold African society. In an illuminating essay on how they used European and African traditions to legitimize colonial rule, T. O. Ranger pointed scholars to the ramifications of codifying customary law. ${ }^{7}$ As Mann and Roberts

${ }^{4}$ It is my impression that this stance was also common in the Colonial Office, if not elsewhere. The Africa Studies Branch of the Colonial Office assessed the Belgian method of collecting customary law, whereby officers on occasion prepared articles and significant cases were transcribed. The CO thought this long-term method much preferable to a study completed in one or two years: "The custom reduced to writing in [the latter] way is inevitably the custom at one point in its growth. Yet it is difficult to judge with certainty whether customary law is ripe for reduction to writing at any one stage of its evolution'. Administrators also then ran the risk of arbitrarily favoring 'old' or 'new' custom. This file is not dated, but appears to be from I 948. (KNA: RR 8/ I [Recording Native Law]; a later version of this paper appeared as 'Methods of recording native customary law', Fournal of African Administration, I[1949], I 30-6). Similarly, in I 95 I, the CO sent out a circular proposing the collection of cases and decisions made in district officers' (DOs') courts 'illustrative of the content of native law in Africa as it exists at the present day'. The circular emphasized that decisions so collected would not be regarded as 'a body of binding precedent', but rather as a set of information about the law. One of the reasons given for this, and the only reason near which the Kenya reader scribbled a check mark, was that 'custom is changing very rapidly in Africa at present time and anything leading to crystallization of custom in its present form is undesirable'. Circular Despatch of 25 Sept. I95 I, KNA: ARC (MAA) 2/10/2 I.

${ }^{5}$ Frederick Cooper, From Slaves to Squatters (New Haven, I980), I I I-2 I.

${ }^{6}$ Provincial African Courts Officer (PACO) Central, to District Commissioners (DCs) Central, 2 July i 957, KNA: RR/8/8.

7 Terence Ranger, 'The invention of tradition in colonial Africa', in Eric Hobsbawm and Terence Ranger (eds.), The Invention of Tradition (Cambridge, I 983), 2 I I-62. The use of the term codification has been rather loose. Ranger never makes explicit what he means by codification, but he appears to include a range of acts including writing down court decisions and the colonial collection of customary law. Chanock reserves the term for the inclusion of customary law into a legal code, which then takes its place next to statutory law (Martin Chanock, Law, Custom and Social Order [Cambridge, 1985]). A clarification of Chanock's argument is here in order, having apparently been misinterpreted by other scholars. Chanock shows quite clearly that early colonial officials sifted through various, often contradictory, statements on customary law to pick out (what they understood to be) the fundamental rules involved. These rules - now rigid and unbending, very much unlike fluid and shifting pre-colonial customary law - could then be strictly applied by Europeans in future cases. Many of these 'customary laws' were tucked away in colonial files or published in anthropological journals. This, however, was not codification. Only from sometime in the I930s and I940s, Chanock argues, were administrators ready to accept the need for codification of customary law - of writing a single version of customary laws into a legal code. Roberts and Mann, who at other points in their essay follow Chanock's basic periodization, lump colonial treatment of customary law into one general argument: 'The invention and eventual codification of custom solidified fluid cultural and legal ideas and relationships into reproducible rules' (Richard 
articulated this, the 'invention and eventual codification of custom solidified fluid cultural and legal ideas and relationships into reproducible rules'. These rules were not only reproducible, but unalterable; codification 'crystallized' customary law. Whereas chiefs and elders had been able to interpret customary law situationally, the colonial state created a single customary law applicable to all disputes regardless of particular circumstances. Colonial officials codified the law based on information provided by elders, thus instituting rules that permanently favored them to the disadvantage of women and junior men. ${ }^{9}$

The evidence from Kenya suggests a different interpretation of these issues. Far from creating a new customary law through codification, from at least the late I920s, few administrators spoke in favor of codification. A crystallized, unalterable customary law would allow them little room to adjust the law in order to control local African courts and, by extension, African societies. In the same way, a non-codified customary law meant that only those who 'knew the African', that is, district officers, could preside over intra-African legal matters. African courts and African life could thus be kept isolated from the overly-technical and arcane judiciary, thought to be illogical to African minds and thus encourage flouting of the law. The state did not create and crystallize customary law, but allowed it to remain fluid and situational.

Even so, in practice it was usually Africans in African courts, not administrators, who determined the real content and interpretation of customary law. In other areas of law and order-policing and the implementation of criminal law - the state tried to extend its control over African conduct and so ultimately exert its hegemony over African life, but these attempts often ended in failure. ${ }^{10}$ Similarly, the state ended up having rather little say in such crucial areas as intra-African disputes, a particularly notable omission in the midst of the second colonial occupation of the postwar years. Judges and district officers may well have dredged the murky waters of administrative knowledge, hoping to snag relevant 'custom' liable to application as law in white courts, but (certainly by I 930, if not before) few

Roberts and Kristin Mann, 'Law in colonial Africa', in Kristin Mann and Richard Roberts [eds.], Law in Colonial Africa [Portsmouth, NH, I 99I], 4). In these terms, the following discussion of colonial rejection of codification responds to Chanock's strict definition of codification; the discussion of how customary law was used in courts responds to the broader interpretation of codification as a code and/or as the collection and writing down of customary law.

8 Roberts and Mann, 'Law in colonial Africa', 4.

${ }^{9}$ Martin Chanock, 'Making customary law: men, women and courts in colonial Northern Rhodesia', in Margaret Jean Hay and Marcia Wright (eds.), African Women and the Law (Boston University Papers on Africa, 7, I982), 53-67; Chanock, Law, Custom; Elizabeth Schmidt, Peasants, Traders and Wives (Portsmouth, NH, 1992).

10 David Anderson, 'Stock theft and moral economy in colonial Kenya', Africa, 56 (1986), 399-4I5; David Anderson, 'Policing the settler state: colonial hegemony in Kenya, I900-1952', in Dagmar Engels and Shula Marks (eds.), Contesting Colonial Hegemony: State and Society in Africa and India (London, I 994), 248-64; Justin Willis, 'Thieves, drunkards and vagrants: defining crime in colonial Mombasa, 1902-32', in David M. Anderson and David Killingray (eds.), Policing the Empire: Government, Authority and Control, I830-I940 (Manchester, I99I), 219-35. 
intra-African disputes ever came before British officials in Kenya. In I 942, for example, less than 3 per cent of the nearly 34,000 civil cases heard by African courts ${ }^{11}$ were later appealed to European administrators. Of the 60,000 criminal cases heard by African courts that year, only $0 \cdot 2$ per cent subsequently went before an administrative officer. ${ }^{12}$

Europeans and Africans remained committed to keeping customary law fluid. District officers sought customary law not in unalterable rules tucked deep in elders' minds, but in the realm of public opinion: thus as public opinion changed so too did customary law. The spotty administrative supervision of how African court elders made their judgements meant that even when Kenya Africans and Europeans did write down authoritative versions of customary law, elders could (and did) continue to apply customary law situationally in the courts. As Chanock has argued, scholars should not view the 'customary law' found in colonial and anthropological essays as true renditions of pre-colonial law, nor should they take it as evidence of how African court elders actually decided cases.

But would not the men who served as African court elders employ the same version of customary law that they provided to colonial administrators? An examination of transcripts from African court proceedings from South Nyanza district demonstrates that elders followed a much more nuanced customary law in the courts than the one spelled out in colonial texts; again, customary law changed to meet altering conditions. ${ }^{13}$ Administrators had much less control over African legal matters than scholars have given them credit for - and than Lugard would have wished - thus pointing out some of the limits of colonial power.

\section{CODIFICATION AS A THREAT TO ADMINISTRATIVE POWER}

Whatever their ideas about the primitive nature of African law, administrative officers did not suppose that it would cease to evolve, and in fact much policy in regard to customary law was based on the premise that law continually changed to meet new circumstances. Colonial officials thus saw customary law both as a tool with which to push African societies toward a desired goal and as a reflection of contemporary balances of power. Customary law should not be hitched solely to the needs of 'the men in trousers', leaving 'the men in blankets' with neither power nor rights in a

11 In Kenya, these were known first as native tribunals, later native courts, and finally African courts.

12 These statistics come from the eight busiest districts in terms of tribunal cases heard in I 942: North, Central and South Kavirondo; Nyeri; Fort Hall; Kiambu; Embu; and Meru. Very few cases came directly to a DO, and these were statutory (not customary law) matters: murder, for example, or non-bridewealth disputes arising out of Christian marriages. See Arthur Phillips, Report on Native Tribunals (Nairobi: Government Printer, Colony and Protectorate of Kenya, I 945), 5-6 on the powers of Native Tribunals, and $2 \mathrm{I}, 24,30,43,58,6 \mathrm{I}, 8 \mathrm{I}, 98$, and 106 for the number of cases heard by the various courts.

13 This argument is similar to those of Sally Falk Moore in Social Facts and Fabrications (Cambridge, I 986) and of Sara Berry in No Condition is Permanent (Madison, I 993). 
brutal new world; at the same time, district officers believed, the law could not remain as it was, dragging 'progressive' men back down to the 'primitive' level from which they had doggedly climbed. Customary law would change, but change slowly and under guidance, allowing the vanguard to push forward without completely eclipsing the way of life of their stillliving grandfathers. ${ }^{14}$

The idea of using customary law to shape society was common among colonial officials. ${ }^{15}$ W. M. Hale, a District Commissioner (DC) in Rift Valley province in 1947 , despaired that 'the Africans themselves are beginning to forget their own laws and are no longer enforcing discipline among themselves'. He suggested using customary law, of which 'there is so much good', to maintain tribal integrity and keep the younger generation in line. ${ }^{16}$ Similarly, paring off parts of customary law contrary to "natural justice or morality' (those practices which, as Mann and Roberts put it, failed the 'repugnancy test ${ }^{\text {'17}}$ ) was in part intended to elevate African societies closer to the level of British civilization. Administrators understood that customary law was a way to shape society and that changes in society and in law were intimately interconnected.

S. H. Fazan, an officer who served many years in Kenya and was a keen observer of colonial African life, expressed this idea of customary law very well. Whatever the ultimate destiny of customary law, he wrote in I929,

we cannot do without it at present. There is a hope that it may reveal a capacity for evolving on its own account in a way suitable to the changing conditions of Tribal life and better adapted to them than either our own law or the Native law as it stands at present. Consequently we must watch the course of progress, guiding here and restraining there, learning as we go. While we recognize that the communal spirit of native law must in the end give way before advancing individualism, we shall not surrender the fortress to the first onslaught of detribalism, but, as the years go on and one point after another is threatened, we shall decide where to protect the tribal custom and where to let it down gently. ${ }^{18}$

It is in this context that the rejection of codification makes sense. Over and over again, officials described codification as 'crystallization' or 'petrification' of an otherwise evolving set of laws. The Chief Secretary put it in perhaps classic terms: "changing conditions [in Kenya] codification would stifle evolution'. ${ }^{19}$ And in I95 I, the Chief Native Commissioner responded to questions in the Legislative Council ( $\mathrm{LegCo}$ ) regarding the rapid dis-

14 Colonial officers in Fiji held similar ideas about Fijian customary law, though not for Indian workers living there. See John D. Kelly, 'Fear of culture: British regulation of Indian marriage in post-indenture Fiji', Ethnohistory 36 (г 989), 372-9 I. In India, the British did codify 'ancient' local law in the nineteenth century, but were torn as to how this might adversely affect continuing change of that law. See Neeladri Bhattacharya, 'Remaking custom: the discourse and practice of colonial codification', in R. Champakalakshmi and S. Gopal (eds.), Tradition, Dissent and Ideology (Delhi, I996), 20-5 I.

15 Schmidt, Peasants, ro6-1o.

${ }_{16}$ W. M. Hale to Provincial Commissioner (PC) Rift Valley (RV), 3 July i 947, KNA: $\mathrm{RR} / 8 / \mathrm{I}$.

17 'Law in colonial Africa', I3.

18 'Memorandum regarding the development of native tribunals', $c$. Aug. I 929, in Rhodes House MSS Afr. s I792, box 37 (Matson Papers), File 5/I, Rhodes House Library, Oxford University.

19 W. S. Marchant to Bulkley, 2 I Feb. I 946, KNA: MAA 7/725. 
appearance of 'good' African customs, with the retort that customary law 'of course is changing fast', which was a thing right and proper, 'and I would emphasize that a code of customary law is certainly not a thing that is desirable' ${ }^{20}$

As independence loomed, however, the Colonial Office pushed codification via the Restatment of African Law project. Nonetheless, opposition among Kenya field officers remained. R. E. Wainwright warned in I 960 that he had recently discovered

quite a large body of opposition to the recording of civil as opposed to criminal law, owing to the difficulty of preventing it from crystallizing unless an expensive system for re-examining and restating it at sufficiently short intervals is set up. It is, of course, true that at the present moment in Kenya such customs as land tenure, bride price, etc. are changing at a fantastic rate, and it is indeed necessary that they should change as fast as possible. ${ }^{21}$

New societies created new laws, and new laws shaped new societies. Codifying law might reflect the interests of elites at a point in time, not necessarily a bad thing, but as society progressed, the usefulness of yesterday's laws would soon be left behind. 'Crystallization' of the law thus created a potential road block to modernity; keeping customary law fluid allowed officers to alter or invent law to retard, redirect or reinvigorate social change. ${ }^{22}$

\section{Customary law, African courts and the judiciary}

This understanding of customary law explains why administrative officers so jealously fought any perceived threat to their control over the law or over the bodies which applied it, the African courts. As one officer put it, the 'Native Tribunal in a Native Reserve is normally the power behind the throne'. When the idea of a Judicial Adviser (JA) was first broached, with the implication that he would have authority over tribunals and would be housed in the Judicial Department rather than the Administration, he reacted with some agitation. The judiciary, he fumed, 'are apparently determined to minimize that power [over the Reserve] to such an extent as actively to interfere with district administration ' ${ }^{23}$ Customary law and the courts were the two tools the administration used to sculpt African society, and any attempt to blunt those tools met fierce resistance. ${ }^{24}$ Indeed, the judiciary often seemed the greatest threat to administrative control over matters of law and order. DOs struggled continuously to keep English law and legal traditions out of African courts. Administrative officers harped on what they

${ }^{20}$ CNC in LegCo, 2 I Feb. I95 I, KNA: RR I/4.

21 Wainwright to Allot, i2 May i 96o, KNA: RR 8/8.

${ }^{22}$ See also, for example, a minute from a PCs' meeting in which legislative interference with bridewealth was rejected. Not only hard to enforce, legislation 'would write bride price firmly into the law, crystallising the custom and making it difficult if not impossible for it to die out'. PCs' meeting of 5 Apr. I938, quoted in CNC's memorandum, 'Bride price', 29 Oct. I94I, KNA: MDS 2/3/3.

${ }^{23}$ Coutts, DO, quoted in extract from minutes of DCs meeting, Officer i/c Northern Frontier District to Chief Secretary, 24 Dec. I942, KNA: MAA 7/395.

${ }^{24}$ See also Fazan, 'Memorandum', i 8. 
saw as the judiciary's undue attention to technicalities, which too often allowed guilty men to walk free. The intricacies of English law, they continued, could not be comprehended by Africans. If the judiciary was allowed to interfere with local disputes, Africans would view colonial law as arbitrary and manifestly unjust. ${ }^{25}$

From the earliest days of British rule in Kenya, members of the administration and the judiciary battled over who would control the dispensation of justice to Africans. In the first decades of colonial rule, litigants could appeal from a Native Tribunal to a Magistrate, and from there up to the Supreme Court. The administration scored a significant victory with the Native Tribunals Ordinance of I930, which effectively separated African courts from most of the judicial system headed by the Supreme Court. The Ordinance authorized appeal from a tribunal to an African court of appeal, and from there to a DO and the PC. From there, excepting cases such as marriage, inheritance and immovable property in a reserve, an African litigant could appeal to the Supreme Court. With the African Courts Ordinance of I95 I, this link became even more tenuous: the ultimate court of appeal for Africans became the Court of Review, which empaneled the Chief Native Commissioner, the Judicial Advisor and the Chief Justice or someone he might appoint. ${ }^{26}$ Essentially, Kenya now had two parallel court systems, one under the administration for Africans and another under the judiciary for others. ${ }^{27}$

Still, administrative officers harbored suspicions that the judiciary was plotting to regain control over the African courts or, through resident magistrates, over local intra-African disputes. A commission of inquiry in I 933 (the 'Bushe Commission', which included the Kenya Attorney General) condemned administrative justice, provoking a storm of angry recriminations from the Acting Governor on down the administrative ladder and

25 These opinions were shared by many white settlers, administrators' erstwhile enemies. See Brett L. Shadle, 'Traitors to their own community: divisions among whites in the Kenya black peril, I926', unpublished paper, Oct. I996; KNA: Jud I/ I465 (Administration of the Law).

${ }^{26}$ For details on these changes, see KNA: RR I/4 (Proposed Amendments to the NTO I930: New African Courts Bill) and RR I/6 (African Courts: Policy and Organization). On some earlier debates in I923-24, see KNA: Jud I/I I04 (Native Tribunals). A brief history of Native Tribunals is given in Phillips, Report, 5-12. For struggles between the judiciary and the administration, see H. F. Morris and James S. Read, Indirect Rule and the Search for Fustice (Oxford, I972), ch. 3. These authors argue that in the post-war years changes in the nature of colonial rule brought about DOs' acquiescence to greater judicial control over local Resident Magistrates. While this may be true, DOs continued to claim sole authority over African courts, where most intraAfrican disputes were heard. Desmond O'Hagan, a former colonial official in Kenya who served as Native Courts Officer, recalled that ' $[\mathrm{m}]$ ost Administrative Officers were of opinion that African courts were more likely to deliver justice than young magistrates untrained in native law and custom'. Personal communication, i 6 Feb. I998.

27 African courts handled customary law disputes, involving matters such as bridewealth, adultery, elopement and land. They also heard select offenses under the Penal Code (for example, assault and, from I 950, indecent assault) and African District Council bye-laws (such as controlling beer-parties or keeping paths clear). Disputes involving whites or Asians, and the more serious Penal Code infractions (rape, murder) were heard by magistrates and could be appealed up to the Supreme Court. Muslims could take disputes to the local Islamic court. 
increasing officers' hostility to the judiciary. ${ }^{28}$ Later, A. J. F. Simmance, DC at Kiambu, bristled when told by the Solicitor General (in Simmance's words): 'it is widely held in official legal circles that African courts must be reduced to considering issues of native law only... must be replaced by Magistrates in all important matters and must... be encouraged to decay and die'. ${ }^{29}$ Even the weak link between African courts and the Supreme Court that existed after I95 I bothered some DOs: 'It is fundamental', the DCs of Central Province resolved in I 954, 'that African Courts should be kept apart from the Supreme Court, and that the Chairman of the Court of Review should not be a Judge of the Supreme Court'. ${ }^{30}$ The creation of the post of Judicial Adviser (who would oversee the much-needed regularization of African courts) prompted a flurry of writing by administrators demanding that the JA be responsible to the Chief Native Commissioner and not the judiciary, and that while the JA might reasonably be expected to be a lawyer, no man without administrative experience should be considered for the job. ${ }^{31}$

Indeed, the administration argued that in the absence of codification, the judiciary did not have the ability to deal with intra-African disputes. African courts operated in the realm of customary law, so those supervising or taking appeals from the courts had to have a firm command of the particular 'tribal' law concerned. But without codification such law could not be learned from the weighty tomes favored by legal students. Only those individuals with an intimate knowledge of the 'tribe' involved could claim a detailed understanding of the relevant points of law, and for DOs this kind of knowledge epitomized their own roles. ${ }^{32}$ Simply put, only administrators could settle customary law cases since only they knew customary law. ${ }^{33}$

This logic was made explicit in I959, when one member raised a question

28 Morris and Read, Indirect Rule, 98-103; Y. P. Ghai and J. P. W. B. McAuslan, Public Law and Political Change in Kenya (London, I970), I44-7.

${ }^{29}$ Simmance to PC Central, 23 Sept. I958, KNA: RR I/6. Similarly, the PC of Central Province felt 'strongly that the African Courts are still an integral part of the Administration, and should be kept firmly under our wing'. PC Central to ACO, I Sept. I 954, KNA: RR i/6.

${ }^{30}$ Minute 2/54 of DCs Meeting, enclosed in PC Central to ACO, I 5 Mar. I 954, KNA: RR I/6. Pencilled in the margin of this document, apparently by then ACO M. N. Evans, was a contrary opinion. "I am in "fundamental" disagreement. This is a parochial and short-sighted view, which runs counter to well-established principles - The Rule of Law in fact. The Executive cannot forever run its own private system of courts, entirely independent of the Supreme Court - particularly where criminal law is concerned'. This comment exposes some of the divergences within administrative opinion, but on the whole these disagreements were less significant than those between administrators and the judiciary.

31 See KNA: ARC (MAA) 2/10/2 I (Native Tribunals: General, I94I-52).

32 See Bruce Berman, Control and Crisis in Colonial Kenya (London, 1990), 88-9. Morris and Read describe this as the 'intimate knowledge which the administrative officer believed he possessed, both of the customary law and of the outlook and social conditions of the African population'. Indirect Rule, 78 .

${ }^{33}$ As a former colonial official (who worked in the provincial administration and later was involved in overseeing African court work) put it, 'I envisioned that African Courts of some kind or other would be required as long as the prime duty of the courts was to administer the customary law of the area concerned, which a trained legal expert could not be expected to do to the satisfaction of the local population' (personal communication, E. [anonymity requested], 23 Jan. I998). 
in the LegCo inquiring when African courts would come under the control of the judiciary. The African Courts Officer's proposed response was that the government had no such plans at present: in part because customary law remained unwritten. 'Since these customs and laws have yet to be codified', he wrote, 'it would not be equitable or possible to expect the Central Judiciary to handle such cases'. While the Permanent Secretary for African Affairs scribbled his agreement in the margin, the Minister of African Affairs ultimately provided the LegCo with an answer more sensitive to the sentiments of the judiciary and African politicians. ${ }^{34}$ While unwritten customary law allowed greater administrative control over African courts and African life, it also provided the administration a convenient excuse to preclude undue meddling by the judiciary. ${ }^{35}$

Colonial officials felt the best tools they had to guide the development of African societies were the African courts. But if they codified the law applied by the courts, DOs were left very little room to maneuver, and it threatened to open the door to judicial interference. While administrators saw on appeal only a fraction of the customary law cases filed in African courts, what mattered was not that DOs should hear every case, but that they, and not the judiciary or any other 'outsiders', could guide the African courts in the handling of such cases. These battles with the judiciary were part of larger struggles between the field administration and 'outsiders' (including white settlers, African politicians and technical officers), but while the judiciary was the primary opponent in codification wars, DOs felt that African courts needed protection from all non-administrators. ${ }^{36}$ At the same time, however,

${ }^{34}$ Question from the LegCo to Secretary for African Affairs, I9 Mar. I 959; ACO A. Galton-Fenzi to Permanent Secretary for African Affairs, I 2 Mar. I959; Minister for African Affairs, reply to oral question in LegCo, I 5 Apr. I959; all in KNA: RR I/6. Similarly, in I95 I, a proposal was made in the Legislative Council to introduce advocates into courts at the DOs' appeal level and above. In his response in the LegCo, the Acting Solicitor General concurred as to the ability of advocates to master many codes of written law. However, 'the intricacies of African law are locked away in the deep recesses of the minds of the African Elders who administer that law'. How advocates could appreciate unwritten customary law, he remarked, 'it is difficult to see'. LegCo, 24 Oct. I95 I, in $\mathrm{KNA}: \mathrm{RR} / \mathrm{I} / 4$.

${ }^{35}$ The members of the Judiciary did not, of course, take all this quietly. Pickering, Judge of the High Court in I 9 19, agreed that law and society evolved together. 'Economic and social standards' related directly to the law, so that if 'the laws are stationary, progress in other matters of life is most difficult'. Thus this maintenance of 'superstitious and nebulous' customary law, the contents of which 'no one ever can know', meant preserving African life in a backward stage. By extending British courts and British justice, modern law could push the evolution of Africa. J. H. Pickering, 3 Oct. I9r9, KNA: Jud I/975. Chief Justice Barth, commenting on a newly proposed line of appeals ending with the Governor and avoiding the Supreme court, rejected arguments that judges were unfamiliar with customary law: this argument 'applies with equal force to a Governor who may never have served in Africa or in any other Colony'. J. W. Barth to Attorney General, 22 Feb. 1930, KNA: Jud r/1096.

${ }^{36}$ Like administrators and their African courts, settlers called for informal African tribunals on white farms, which they hoped would fall under settler influence. Some extra-legal bodies were in fact established, but administrators fought fiercely against this expansion of settler authority over Africans. On settler tribunals, see Tabitha Kanogo, Squatters and the Roots of Mau Mau (London, 1987), 75; and on debates in the administration over extending recognition to them, see KNA files ARC (MAA) 2/I0/2 I; Jud I/975 (Native Tribunals, I9I6); Jud I/I Io4. 
some of the more legally-minded officers opposed codification in favor of the slow collection of recorded case law, which eventually could serve as precedent, following British legal traditions in this regard. ${ }^{37}$

THE BATTLES OVER CODIFICATION

While the administration's rejection of codification appears in the archives as early as I923, and becomes more regular between I 945 and independence, the increasing attention to regularizing the African courts produced questions about writing down or codifying customary law. This in turn forced administrative officers more explicitly to defend their control of the courts, and so reject codification. Tracing these debates allows a better appreciation of administrative resistance to codification.

\section{The Fazan Memorandum}

In May I 929, the DCs of Kikuyu province passed a resolution proposing that Native Tribunals should not be linked to the Supreme Court. At the request of the Senior Commissioner, S. H. Fazan (DC of South Nyeri) prepared a memorandum explaining the rationale behind the DCs' resolution. Fazan saw two paths that the Native Tribunals might follow: they could be treated like subordinate British courts (which would allow customary law to disappear within British and statutory laws) or the tribunals and customary law could be maintained as separate institutions. The importance Fazan attached to customary law ('we cannot do without it at present') led him to argue for the second path. ${ }^{38}$

Fazan anticipated counter arguments that the right of appeal from tribunals to the Supreme Court would not necessarily destroy customary law. Indeed, the Supreme Court heard appeals from Muslim courts without altering Islamic law. The difference, Fazan pointed out, was that Islamic law was a 'written code based on a religion and a system we cannot ignore'. The Supreme Court, Fazan worried, would treat unwritten customary law very differently. Unlike Islamic law, he argued, African customary law was 'based on a system of life which is recognized as anterior to civilization' and was 'not reinforced by anything more authoritative than the commentaries of European Officers and Missionaries'. Supreme court judges would thus feel little compunction in radically remaking or discarding customary law. Fazan pointed to the Supreme Courts in Cape Colony and in Kenya, each of which had ruled that a customary law marriage was little more than illicit sex; this position was not reversed until the Kenya state officially recognized such marriages. 'That is to say', Fazan wrote, 'that a piece of native custom has to find its way into an Ordinance before it is recognized by the Courts'. ${ }^{39}$ Fazan concluded that to ensure customary law would receive more than 'perfunctory recognition' by the Supreme Court, it would have to be codified.

For Fazan, however, 'the objections to a Code are very grave', as he detailed in his analysis of the Natal Native Code, first enacted in I 878. The

\footnotetext{
37 Oliver Knowles, personal communication, 26 Jan. I 997.

38 'Memorandum', 6-7.
} 
code included laws governing, among other things, the status of women, the authority of kraal heads and bridewealth exchanges. ${ }^{40}$ The Natal government also established a board that would occasionally review the Code 'so that it might not become stereotyped and act as a barrier against native advance', but 'hampered with restrictions', the review board had not been able to enact a single amendment. Finally revised in I89I, the Code then could be altered only by Parliament, but Fazan quoted Professor Brookes: 'Parliament has neither the time, the interest nor the expert knowledge to do so'. Two different commissions, Fazan reported, had since come down against the Code. ${ }^{41}$ The history of the Natal Code and its condemnation by the commissions served to "strengthen the opinion which is induced by our own independent experience that a Code is on no account to be attempted'. ${ }^{42}$

\section{The Natal Code}

A more widespread discussion of codification arose after circulation of the Natal Code in 1946-7. A copy of the Code was sent to the Chief Secretary (CS) for consideration by Bulkley, a former Kenya official resident in South Africa. The CS reminded Bulkley that 'we have always felt that in the changing conditions here codification would stifle evolution', but he sought out comments from field officers nonetheless. ${ }^{43} \mathrm{H}$. E. Lambert, a DC in Central Province and a recognized expert on customary law, noted with pleasure that the code could 'hardly be considered a complete codification of native customary law at all', but more a set of 'general principles' leaving customary law itself 'untouched and very largely undefined'. ${ }^{44}$ In a set of notes Lambert drafted and sent with the Natal Code to all field officers, he explicitly stated it was 'not intended...to attempt any codification of the native laws of Kenya' but simply to gather comments on the South African methods. ${ }^{45}$

Despite Lambert's reassurances, most administrative officers reacted suspiciously. R. S. Winser, DO in charge of Native Tribunals in South Kavirondo, agreed that codification of customary law 'should be of inestimable value when the day comes', but thorough investigation was first required; thus codification should come no time soon. ${ }^{46}$ Summarizing the opinion in Nyanza, the PC echoed that it was 'too early' to attempt codification. ${ }^{47}$ The DCs in Rift Valley expressed mixed emotions. F. A.

\footnotetext{
40 On the origins of the Natal Code, see Thomas McClendon, 'Tradition and domestic struggle in the courtroom: customary law and the control of women in segregation-era Natal', International Fournal of African Historical Studies 28 (I995), 527-6r.

41 These were the Cape Laws and Customs Commission of 1893 , and the South African Native Commission of I $905 . \quad 42$ 'Memorandum', I I.

${ }^{43}$ W. S. Marchant to Bulkley, 2 I Feb. I946, KNA: MAA 7/725. As early as I 923, one settler turned administrator argued that something like the Natal Code was needed in Kenya, but his idea apparently found little resonance within administrative circles. Assistant DC to DC Kyambu, i 4 May i 923 , KNA: Jud i/ i io4.

${ }^{44}$ Lambert to Marchant, 23 Mar. I 946, KNA: MAA 7/725.

${ }^{45}$ Draft notes by Lambert, n.d., KNA: MAA $7 / 725$.

46 In A. A. M. Lawrence, DC South Kavirondo (SK), to Acting PC Nyanza, 2 I May I 947, KNA: MAA 7/725. ${ }^{47}$ PC Nyanza to CS, I 4 July i 947, KNA: MAA 7/725.
} 
Loyd argued that as customary law in 'the more advanced Reserves... is changing rapidly' codification should be put off for some time, and then done only within a flexible framework. W. M. Hale was more enamored with the idea, given his impression that customary law was being rapidly forgotten. G. E. Noad, DC at Nakuru, also agreed that the Code looked promising, but felt it better suited for the more homogeneous Natal (where he had 'only heard the natives referred to as "Kaffirs"') than heterogeneous Kenya. DCs from Central Province apparently read Lambert more closely, and critiqued the Code itself for shifting power away from local indigenous authorities and toward the colonial state. ${ }^{48}$

While all despaired over the decline of tribal discipline, most administrative officers balked at centralized, inflexible solutions to this problem. Even a loose set of guidelines like the Natal Code provoked fear of stunting legal, and hence social, evolution. Much as the Chief Secretary must have expected, the response of field officers sank the idea of a similar code for Kenya, and the matter was not brought up again.

\section{The customary law panels}

Arthur Phillips' 1944 Report on Native Tribunals sparked a rather longer series of discussions of customary law. In I943, the Chief Secretary appointed Phillips, Crown Counsel, to investigate the workings of the tribunal system in Kenya ${ }^{49}$ Possessing both legal training and administrative experience, Phillips garnered some trust among field officers. His Report provides unique insights into the history and operation of the African courts, and it outlines his own policy recommendations, which carried more weight with his appointment as Judicial Advisor in I 948.

Phillips felt that improvement and professionalization of the tribunals required some steps towards written law. In the Report, and again in a memo to the Chief Secretary, he stressed the 'need for greater certainty in native law and for closer control over its development'. More controversially, he recommended 'if these objects are to be achieved native law cannot remain purely unwritten'. Still, he remained cautious, suggesting only 'preliminary steps of an experimental nature', including an analysis of existing material to provide a scheme for future research, the appointment of local customary law advisory panels, and the 'preliminary study' of certain areas like land tenure. Despite these limited proposals, the Chief Native Commissioner felt compelled to reiterate 'the danger of codifying Native Law', although he reluctantly agreed to Phillips' plan. Similarly, a meeting of DCs from Rift Valley Province critiqued the idea, saying it was too early to consider codification. ${ }^{50}$

Some idea of what Phillips had in mind can be gained by examining Hans Cory and M. M. Hartnoll's Customary Law of the Haya Tribe, Tanganyika Territory. ${ }^{51}$ In 1946 , Phillips suggested a copy of the study be circulated

${ }^{48}$ F. A. Loyd to PC RV, i 8 June I 947 ; W. M. Hale to PC RV, 3 July I 947 ; G. E. Noad to PC RV, 8 July I 947; PC Central to CS, I 5 Mar. I948, all in KNA: RR/8/ .

49 Phillips, Report, I.

50 Ibid. I; Arthur Phillips to CS, 26 Mar. I 945, KNA: ARC (MAA) 2/10/2 I ; Minute 38/45, PCs meeting, Io-I 4 Apr. I 945; Acting PC RV to CS, I 4 Aug. I 945, all in KNA: MAA $7 / 725$.

51 London, 1945 . 
among officers in Nyanza and Central Provinces 'with a view to giving administrative officers an idea of the possibilities of recording native law'.52 Like most administrators, Cory and Hartnoll viewed customary law as evolving alongside society, and where it remained unwritten 'the courts naturally had wide discretion, and their interpretation and alterations were readily accepted'. But when outside influences (like European civilization) caused rapid changes in basic social principles, customary law ('itself the expression of those principles') took some time to adjust to those new conditions. Cory and Hartnoll thus assumed that in the coming years Haya customary law would more and more reflect Western culture, 'and therefore, apart from any other reason, this book can in no way be considered a code but is a collection of customary law as it stands at present ${ }^{3}{ }^{53}$ Given this approach, the authors were free to point out areas of Haya customary law over which elders disagreed, or which differed between the various kingdoms ${ }^{54}$ Phillips' recommendation of this work suggests he approved of their idea of collecting, though not codifying, customary law.

Though Phillips' plans were not forgotten, the wartime shortage of personnel meant it would not be implemented for some years. Only when the position of Judicial Advisor gained approval in 1948 and Provincial Native Courts Officers were appointed for Nyanza and Central provinces did any framework exist to begin the collection of customary law. Then, often fitfully, administrators established district-level law panels (divided when necessary into different ethnic sections). The members of the panels included chiefs, African court presidents and members, and other representatives of the community: African ministers, younger 'progressive' men and occasionally a woman. ${ }^{55}$ These panels had as their goal, a South Nyanza DO explained, to 'discuss and record Native Law and Custom as they were, as they are today and as they are changing'. ${ }^{56}$ There was no intention of codifying the law, as the Native Courts Officer (as the Judicial Advisor was now known) made perfectly clear. ${ }^{57}$ The activities of the law panels did,

${ }^{52}$ Phillips to CNC, 20 July r 946, KNA: MAA 7/725. The worth of Cory and Hartnoll's study was reaffirmed by the African Studies Branch of the Colonial Office, in 'Methods of recording', I30-6.

${ }_{54}$ See, for example, $35^{-6}, 46,54,65,67,73,80$, and I I I.

55 For membership of the Luo and Kisii sections of the South Nyanza Law Panel (SNLP), see KNA: RR 8/ı (Native Law: Law Panels, South Nyanza). Membership of the later ethnic law panels is listed in Appendix B of Eugene Cotran, Restatement of African Law: Kenya: Volume I, Marriage and Divorce (London, I968).

${ }_{56}$ Minute I/50, SNLP, 27 Sept. I950, KNA: DP/18/13.

57 See NCO to T. Watts, Provincial Native Courts Officer (PNCO) Nyanza, 22 Sept. I 949, KNA: RR ı/4; NCO to DC Kitui, I2 Apr. I948, KNA: RR 8/ r. In I 95 I, a DO named Andere wrote to Audrey Richards to request 'any suggestions as to what [he] should do' in his role as the North Nyanza Law Panel Secretary. A shocked Richards immediately wrote to the ACO, expressing her disbelief that a man without any training had been put to 'such a very tricky business'. The ACO responded by informing her that there was 'no intention of attempting to codify customary law or to bind the African courts by the findings of the Law Panels'. So even if through his inexperience Andere made mistakes, 'no great harm will be done'. Andere to Richards, I 3 Jan. I 95 I ; Richards to Cowley, 7 Feb. I95 I Cowley to Richards, 9 Mar. I95 I, all in KNA: RR 8/ı. At one point in I955, the DO in charge of courts proposed that the minutes of the SNLP be published as a booklet and distributed to the African courts: 'the courts would then apply the customary law as laid down in the book,' and any deviations would have to be justified 
however, lead a few officers to understand law panel minutes to be the sole customary law applicable in intra-tribal disputes. Still, these administrators also believed that the collection of customary law by the panels was not an end but a beginning, a 'means of changing traditions to meet current altering conditions'. 58

The comments of Eugene Cotran, who headed the Restatement of African Law project, on the panels are instructive. Cotran toured the colony in the early r96os, sitting with panels and examining old minutes. His condemnation of the law panel system was total. In some districts no panel was ever set up. Those that did meet did so infrequently and followed no systematic pattern in recording the law. Instead, administrative concerns dominated proceedings: if divorce was perceived as a problem, then a meeting would be called to hash out the applicable customary law; the next meeting might address land law, or perhaps customary oaths. The European chairmen often opened law panel meetings and then retired, leaving 'the detailed deliberations to the other members' (which Cotran apparently saw as a bad thing). As Cotran concluded: '[E]ven the best panels simply have a lot of minutes here and there, but no coherent statement on any part of customary law', ${ }^{59}$ nothing close to codification.

\section{AFRICAN COURTS AND CUSTOMARY LAW}

If administrators in Kenya from the I93os rejected codification, it remains to be seen how fluid customary law was in practice. Since law panel members often served as African court elders as well, it would seem that they would apply the same version of customary law they recorded in law panel minutes. But a comparison of the customary law presented to law panels with the customary law used in actual court cases in South Nyanza from the I950s and I960s shows that the latter was not bound by the former. Presiding elders remained committed to a fluid and situational customary law, rather than the more fixed rules recorded in the law panels. Similarly, when DOs needed to ascertain a point of customary law, they too held firm to the belief that customary law could and should change. From at least I 930, administrators had little interest in ancient rules, but looked to 'public opinion' to discover the contemporary definition of the law instead.

\section{Customary law in the law panels and in the African courts}

The way the South Nyanza Law Panel (SNLP) operated did much to blunt any influence it might have had on customary law administered in the courts. After finally being organized in 1948 or 1949 , members of the SNLP appear to have met infrequently. Already by 1952, the DC was forced to admit the

in detail. None of the archives consulted, however, contain any trace of even first steps toward such codification. Minutes of the SNLP (Kisii Section), 5-6 Dec. I956, KNA: RR 8/io.

58 See PACO Central to DCs Central, 2 July r 957; DC Kiambu to PC Central, 28 Aug. I957; ACO to PC Central, 30 Oct. I957, all in KNA: RR 8/8.

59 Eugene Cotran, 'The recording of customary law in Kenya', 3 Jan. I962, KNA: RR 8/8. 
panel 'has rather been in abeyance lately'. It did meet that year, but not again until I954. From then until I956, the Luo and Kisii sections of the panel each met several times, but then fell dormant again until the early i 960 s. $^{60}$

From the few meetings the SNLP did hold, members prepared memoranda on certain areas of customary law, some of which can be compared to transcripts from African courts. For example, in I954, the Luo and Gusii sections separately debated customary laws of divorce. Given examples of recent claims for divorce, the Luo section conceded that if a woman was compelled by her husband to sleep with other men, "this may be a strong enough reason for divorce', while the Gusii group simply noted that this was taboo, and that such a woman would have to carry out a cleansing ceremony before resuming conjugal relations with her 'legal husband' ${ }^{61}$ All in all, the panelists took a dim view of divorce.

Yet according to a 1956 study by Oliver Knowles, then officer in charge of courts in South Nyanza, African court elders granted divorces more often than not to dissatisfied women. According to Knowles, slightly over half of divorce petitions in Gusii courts succeeded, while Luo courts granted threequarters of petitions. In comparing court records to the views expressed in the law panels, Knowles noted that the customary law outlined by the panels appeared 'to show fewer departures from tradition than the actual case law decisions being delivered by the courts today'. Thus while Africans presented a rigid customary law on the panels, when deciding actual cases elders "recognize the truth of the maxim that "hard cases make bad law" and give judgement accordingly'. ${ }^{62}$ One year later the situation seems to have remained roughly the same: no single, strict customary law of divorce was being issued by the courts, whatever might have been said in the panels. ${ }^{63}$

The example of adultery bears out this point. In Gusii, this crime ('Adultery contra native law and custom') was used exclusively to punish a man living with another man's wife, rather than illicit intercourse per se. Even if the union was consensual, only the man could be charged. A special meeting held in I 96 I to consider customary criminal offenses outlined how such cases were handled under 'Gusii customary law'. ${ }^{64}$ Members listed only two defenses that would exonerate an accused: the consent of the husband or payment of bridewealth by the accused to the woman's parents. The only

${ }^{60}$ DC South Nyanza to ACO, i 8 Oct. I952, KNA: MAA Io/43. Minutes of the panel can be found in KNA: RR 8/10, and in file MAA/KIS/LAW/I, in the Archives of the Cardinal Otunga History Society (COHS), Cardinal Otunga Secondary School, Mosocho, Kenya, which I used with the kind permission of Brother Anthony Koenig.

${ }^{61}$ Minutes of the SNLP, I954, KNA: RR 8/10.

${ }^{62}$ Oliver Knowles, 'Some modern adaptations of customary law in the settlement of matrimonial disputes in the Luo, Kisii and Kuria tribes of South Nyanza', Fournal of African Administration, 8 ( 1956), I I-I 5 .

${ }^{63}$ At a meeting of the Kisii Section in November I955, meant to focus on divorce law, the new courts officer stated that during his recent inspection 'he had received different views on the points which were to be discussed'. Two points here are noteworthy. First, the decisions made by the law panel in 1954 had not created any binding customary law enforced unquestioningly by court elders. Second, this new courts officer either had not seen or had disregarded the old minutes on the customary law of divorce, showing the disjointedness and disorganization of the collection of customary law. Minutes of the Law Panel (Kisii Section) 28-29 Nov. I 955, KNA: RR 8/ 10.

${ }^{64}$ As part of the Restatement of African Law project. 
extenuating circumstance listed was if the accused 'had no knowledge that the woman was married' ${ }^{65}$

An examination of several hundred adultery cases filed in the r95os and I 960s, however, shows that in deciding disputes, court elders displayed a much more nuanced understanding of this crime ${ }^{66}$ Many cases were quite straightforward. If witnesses confirmed that the complainant had paid bridewealth and his wife had been found living with another man, that man was found guilty. In such instances, the issues were clear: should a man live with another man's wife, he had contravened customary law. But not all cases were that simple, forcing court elders to interpret the law in the light of particular circumstances.

In a case in I959, elders had to weigh the customary claims of a husband over his wife against the expectation that a husband should try to ensure his wife remained at his home. All the parties agreed that the complainant Ondieki had given bridewealth to the parents of Kemunto, and that Kemunto now lived with another man, the accused. But Kemunto rejected Ondieki's claims over her and explained why, despite the payment of bridewealth, she would not return to him: he had beaten her, called her barren, chased her from their home, and had not come looking for her for seven years. Following the law panel, Kemunto's complaints should have been irrelevant to the case, but the court elders agreed that Ondieki could not act in this way and still claim Kemunto as his wife:

By our view, we dismiss this case because Ondieki, since the year 1952 when his wife left his home, he still has not gone after her to bring her home, in addition... he chased away Kemunto... We return Kemunto to her second husband [the accused] because since 1952 she has been his wife and when he wishes he will pay bridewealth. ${ }^{67}$

In a similar case in 1963 , elders Mariga and Onchara made a similar decision: 'This court sees that although the accused has admitted his guilt, the woman has lived for a long time with the accused, that is, three years', and so found him not guilty.$^{68}$ In these and similar cases, elders interpreted customary law of adultery as recognizing the duty of a husband to follow his runaway wife and return her home, within at least one year. The SNLP (of which Mariga was a member) had not listed this as a defense, but the elders simply ignored the panel's interpretation of the law and made their own interpretation to fit the circumstances.

An excellent illustration of the differences between law panel and applied customary law arose in a 1959 adultery dispute. After the complainant made the requisite enumeration of bridewealth paid, his wife spoke. Her husband had accused her of being barren, after having borne no children during their three years together. She had proved this false (by becoming pregnant by the accused) and she vehemently refused to return to the complainant. The

${ }^{65}$ Special Law Panel Meetings to Record Customary Criminal Offenses in Kisii District, Aug. I6 I96ı, COHS: MAA/KIS/LAW/I/ I 3.

${ }^{66}$ I have examined 685 adultery cases heard in the Gusii African courts Ritongo Gesima and Ritongo Kuja between the early i 950 os and mid r96os. The transcripts are in Swahili or, from about 1964, English. The Ritongo Gesima files are now housed in the courthouse in Keroka, those from Ritongo Kuja are at the district headquarters in Ogembo. My thanks to the Resident Magistrate, Kisii, for permission to use these files.
${ }_{67}$ Ritongo Kuja criminal case 673/59.
${ }_{68}$ Ritongo Kuja criminal case $69 / 63$. 
elders (though they did not say so) must have taken this into consideration: 'We see that [the accused] is not guilty in this case, because [the woman] went to his home on her own' ${ }^{69}$ Yet less than two years later the law panel made a special point to note 'it is not a defense to prove that the married woman consented to being removed'. Thus, while the SNLP set out a static version of customary law there is little evidence that the courts actually acted on it. ${ }^{70}$ Indeed, until the mid-I 960 , Gusii courts made no mention of law panel minutes when deciding adultery cases.

It is important to note that elders did generally help husbands reclaim their wives. The above case, in which the elders entered a not guilty verdict because the woman had gone to the accused 'on her own', was unusual. More commonly, elders ignored proof that the wife had gone consensually and found the accused guilty. Similarly, when a woman claimed she had deserted her husband only because she had been forced to marry him, elders usually paid little attention despite a law panel minute that stated nonconsensual unions were not to be considered true marriages. ${ }^{71}$ But while court elders did use their powers to try to contain rebellious women and junior men, the above examples show that they did not do so unquestioningly, nor did they blindly follow law panel minutes. The interpretation of customary law made by African courts elders normally benefited senior men, but given certain circumstances the dispossessed could also find justice.

This examination of how African elders interpreted and implemented customary law also suggests how little authority colonial officials had in these matters. Court elders pursued their own interpretations of customary law with little reference to British ideas, even in such crucial areas as land law. ${ }^{72}$ District officers were supposed to review each African court case to guard

69 Ritongo Kuja criminal case $927 / 59$.

${ }^{70}$ Interviews carried out for me by Ben Omwega with two former Gusii court elders bear out this point. Interviews with Paul Nyangoto Ogeturenga, 24 Oct. 1997, and Nyasani Omanua, 22 Oct. I 997.

${ }_{71}$ Minutes of Kisii (or Gusii) Law Panel, Io-I I Dec. I962, COHS: MAA/KIS/ $\mathrm{LAW} / \mathrm{I} / \mathrm{I} 3$.

${ }_{72}$ The observations of Philip Mayer and Iona Mayer regarding the creation of land law in Gusii are revealing. Resident in the area in the late I940s, the Mayers read hundreds of court files, sat in on the debates of local semi-formal councils of elders (known as etureti) and interviewed court elders and ordinary people. The Gusii, they argued, had had no real land law pre-colonially: land was too plentiful to necessitate such details. As land became more scarce from the i 920 , however, a land law began to emerge:

At times local etureti elders tried to reconcile the disputes without the guidance of legal rules; at other times they applied rules proper to a more familiar type of quarrel, that is, over bridewealth rights. Cases already digested by etureti elders on these lines proceeded to the two native tribunals, where again they were heard by Gusii elders pledged to apply native law and custom. Here they were given further consistency, and the common law began to crystalize, with bridewealth-law features more or less firmly embedded in it. Some cases went further on appeal and reached British magistrates who, reluctant to interfere with native law and custom, made no deliberate alterations of principle.

Far from seeking out and implementing 'rules', administrators were content to allow local Gusii elders and tribunal members to create a new set of customary laws, drawing in large part on the 'customary law' of bridewealth. See Mayer and Mayer, 'Land law in the making', in Hilda Kuper and Leo Kuper (eds.), African Law: Adaptation and Development (Berkeley, 1965), $5 \mathrm{I}-78$. 
against unjust decisions, but the number of such cases overwhelmed DOs in charge of courts, who regularly complained of the amount of work facing them. Only a tiny handful of case files I examined contained anything more than a scribbled initial, suggesting a cursory review. ${ }^{73}$ Only when an officer spent extra time studying an area of customary law (as Knowles did with divorce) did DOs have any real idea of how African court elders were deciding cases. Customary law and African courts - thought to be the "power behind the (administrative) throne' - were rarely under the control of the administration.

\section{Discovering customary law}

As Chanock has suggested, colonial officers thought that one had to dig deep into the recesses of the eldest (male) African minds to discover customary law. ${ }^{74}$ This interpretation of colonial customary law is central to the historiography of codification; DOs sought from elders the 'real' customary laws, which they could then transcribe into hard and fast rules. But by the post-war years (and perhaps as early as the mid-I930s) Kenya colonialists often sought customary law in the more fluid realm of public opinion. In district and provincial appeals courts Europeans still relied on African assessors who could advise on the intricate points of customary law involved. But administrators believed this was not unalterable law; rather, it was the current opinion of the content of customary law. ${ }^{75}$

Debates surrounding bridewealth provide a fitting starting point. The DC of South Kavirondo in 1936 still seemed to think in terms of a set body of customary law when he inquired if the Kuria thought that 'the present bride price is a departure from their ordinary law and custom'. But his method of determining the customary law suggested he had a different understanding of that law. If the present practice was not accepted, he noted 'a record should be made of what they consider is their law and custom, and... this majority opinion could be legally enforced through Tribunals ${ }^{76}$ Customary law was thus not something static but cloudy and open to different interpretations. That 'majority opinion' had determined the proper custom at this point did not preclude the possibility of future changes. If the majority later arrived at a new interpretation of their 'ordinary law and custom', this new version would become legally enforceable law.

Some DOs did believe law panel minutes should be enforced in African courts, yet they also thought customary law should change over time. The possible methods of allowing for this were two. Should every change in customary law be held up for approval by 'African opinion' (ascertained

${ }^{73}$ The remarks of the Attorney General, and later the African Courts Officer, show that officers in Nairobi spent more time examining at least some court returns. For a similar argument on the lack of regular review and supervision of African courts by colonial administrators, see Moore, Social Facts, I49-5 I, I7 I. ${ }^{74}$ Law, Custom, 53.

${ }^{75}$ This was not a point necessarily shared by all administrators. The CNC's I95 I opinion that customary law was 'locked away in the deep recesses of the minds of the African Elders' certainly expresses a different opinion. Yet it is also significant that the $\mathrm{CNC}$ was addressing the Legislative Council when trying to ward off the introduction of English legal traditions into African courts. In such a situation it would certainly have been dangerous to admit just how fluid customary law could be.

${ }^{76}$ DC SK to PC Nyanza, 2 July i 936, KNA: MDS 2/3/3. 
through locational and district councils), they wondered, or should 'progressive' Africans be allowed to push the law ahead 'more rapidly than general opinion would have it do'? That the former option became policy is less interesting than the assumptions within the debate: customary law could be changed, and the way to determine the direction of its change was through public opinion. ${ }^{77}$ While Knowles insisted that law panels were not meant to codify customary law, he had similar ideas about the role of the public in determining customary law. The decisions made by the panel were meant to help 'reduce uncertainty and serve as a forum for crystallizing and rationalizing public opinion'. Courts would not be held by the panels' decisions, but the panels pointed out the direction of change in customary law as dictated by 'public opinion'. ${ }^{78}$

An exchange in 1949 between the Native Courts Officer and the DC of South Kavirondo on the customary law of adultery is also instructive. Reviewing returns from South Kavirondo African courts, the NCO began to 'notice that the punishment on conviction for adultery varies considerably'. 'Is there any standard punishment', he queried the DC, 'for adultery among the Luo or Kisii Tribes...? ?79 The DC replied: 'There is no punishment for Adultery either amongst the Luo, or the Kisii, or indeed among the Suba or Abakuria', the four ethnic groups inhabiting the district. He dutifully detailed the Gusii (Kisii) 'Native Custom' of adultery, but suggested that given the changing pace of life, elders could no longer enforce 'the old tribal taboos (which are subtle and numerous) nor were they in a position to insist on the [post-adultery] cleansing ceremony being properly carried out'. In this situation, the DC explained, to prevent social disintegration the elders felt justified in meting out punishment for adultery. Although this was not hoary tradition, the DO noted, ' $\mathrm{t}$ ] here is rarely an appeal against these heavy sentences and I believe as a whole public opinion would support them'. ${ }^{80}$

This distinction is important, insofar as Chanock argues that reference to ancient customary laws provoked the criminalization of adultery in Northern Rhodesia in the early i 9oos. Elders and chiefs came before DOs in such cases and gave varying stories of how adultery had been punished previously; most of these senior men, anxious to assert their authority over women and juniors, constructed tales of vicious retribution against adulterous couples. Administrators extracted from this evidence what they thought was the kernel of customary law, and so instituted an unalterable rule making adultery criminal. The Kenya case suggests another interpretation of how adultery could be criminalized. With the passage of a new penal code in 1930 to replace the Indian Penal Code, adultery was about to be decriminalized.

77 See PACO Central to DCs Central, 2 July i 957; DC Kiambu to PC Central, 28 Aug. I 957; ACO to PC Central, 30 Oct. I 957, all in KNA: RR 8/8.

${ }_{78}$ Knowles, 'Some modern adaptations', I4-I5. Administrators often noted that African District Councils (composed of chiefs, young progressives and other local notables) could recommend changes in customary law, but had no power whatsoever to actually alter it. Here too the ADCs would enunciate public opinion, but court elders and administrators remained in control of the actual customary law used. See correspondence between PC Coast, PC Nyanza and ACO in 1949 and between the CNC and PC Central in $195^{2}$, all in KNA: RR 8/I.

${ }_{79}$ Desmond O'Hagan to DC SK, I 2 Apr. 1949, and 4 Mar. 1949, in KNA: MAA IO/ 43 .

${ }^{80}$ DC SK to $\mathrm{NCO}, 4$ May i 949 , KNA: MAA ro/43. 
Administrators in Nyanza Province quickly took up the charge, explaining why adultery needed to remain a criminal act: it prevented social disintegration, irate husbands would otherwise resort to violence, and so on. Not once, however, did they argue that adultery had been criminal under customary law and thus should remain so. ${ }^{81}$ The $\mathrm{PC}$ of Coast Province in I 949 admitted that the 'hearing of Adultery Cases in the Criminal Court is in deference to the wishes of African opinion'. ${ }^{82}$

Customary law, in the eyes of these colonial officials, was not an ancient, unchanging esoteric body of knowledge, but rather a set of laws that reflected evolving social conditions. In order to discover the nature of customary law at any point in time it was necessary to tap into public views on that law. It should be admitted that these officers did not feel it necessary to identify who made up the general public: we might guess they meant men, perhaps senior men. ${ }^{83}$ Still, discussing these matters at public meetings did present the opportunity for under-represented members of the community to voice their opinions and so help to create new interpretations of customary law. ${ }^{84}$

\section{CONCLUSION}

Far from promoting the codification of customary law, colonial officials in Kenya fought against it, fearing that it would disrupt their control over local African courts, and hence over African society. At the same time, the law used by African court elders often remained unknown to district officers, and even the customary law that elders outlined to administrators resembled but did not determine that used in courts. Only with the restatement project of the early i 960 did the civil customary laws of Kenya find their way into courtroom manuals, in time becoming de facto if not de jure codes of law. ${ }^{85}$

The conclusions presented here reflect on the very nature of colonial rule and the extent of state influence on daily African life. Customary law and African courts, which colonial officials believed basic to the reproduction of state legitimacy and authority, lay largely outside the purview of the state. How much, then, did the colonial Kenya state directly influence African societies? Certainly the very establishment of African courts and the threat of state sanction that lingered behind them cannot be discounted, but in courtroom debates and decisions - the places where Africans interpreted and reinterpreted the customary laws of marriage and of divorce, of land and of

81 See correspondence in KNA: PC/NZA 3/ i 5/88 (African Courts: Adultery Cases).

${ }^{82}$ PC Coast to NCO, 30 Aug. I 949, KNA: MAA 6/2 I.

${ }^{83}$ In r 932 Clarence Buxton, DC SK, spent some time considering how and where public opinion was formed. 'The Kisii Township market is often attended by as many as 5,000 people and amounts to a social gathering where news can be exchanged. It is perhaps at these gatherings that the real public opinion is formed...' (SK District Annual Report, I932, KNA: KSI/3). That these markets were attended by men and women, young and old, suggests that he may have thought all segments of society contributed to create public opinion.

${ }^{84}$ Here I disagree with Mahmood Mamdani, who argues that colonial officials presumed the existence of a single, indisputable customary law for each tribe, so that those with interpretations different from those of the Native Authorities did not even have the opportunity to make their ideas known. Mamdani, Citizen and Subject : Contemporary Africa and the Legacy of Late Colonialism (Princeton, I996), i i 8.

${ }^{85}$ For an example of this, see Michael Saltman, The Kipsigis: A Case Study in Changing Customary Law (Cambridge, MA, I977), 63-4. 
labor - the state had surprisingly little to say. Sara Berry has suggested that the state did not end debates over customary law, but set the parameters for further debate, ${ }^{86}$ and the parameters may have been loose indeed.

Of course, colonial officials and African elders hoped to twist gender and generational relations into forms more to their liking, and the legal arena served as a particularly useful place to do this. But if customary law in Kenya remained fluid and situational, this suggests that women, juniors and the poor could argue against the dominant interpretation of customary law. ${ }^{87} \mathrm{At}$ the same time senior men and court elders may have had the chance continually to reform customary law to counter the challenges thrown up to their authority. Customary law was a powerful means by which Africans could stake claims over people and resources, and - as it remained noncodified and fluid-every African could shroud his or her argument in a particular interpretation of that law.

\section{SUMMARY}

Scholars have argued that colonial states in British Africa codified previously fluid customary law, making it impervious to change. In Kenya, by contrast, administrators struggled against codification, from at least the r 920 s but with increasing ardor from the I 940 s, for two broad reasons. First, they believed codification crystallized the law, preventing changes necessary in a period of rapid economic and social development. Through continual alteration of a fluid body of customary law, administrators could try to guide these changes and keep a firm hold over African life. Second, codification threatened to empower the judiciary in their ongoing struggles with the administration over the control of African dispute resolution. Keeping customary law unwritten helped exclude the judiciary from intra-African disputes, since without written codes only administrators (who 'knew' Africans) could decide customary law cases.

In actual practice, the identification and use of customary law remained fluid. Administrators believed customary law lay in the shifting realm of 'public opinion', and sought details of the law in this ever evolving arena. Even when Europeans and Africans put customary law to paper, a review of court transcripts shows that African court elders continued to employ law situationally. The Kenya case suggests that while administrators and senior men did hope to use the law to resist challenges from women and juniors, they did not do so via codes of unalterable and unquestionable customary law. This also points out some of the real limits on colonial power. Rather than administrators using customary law to guide development, Africans made their own interpretations of customary law, either in their 'public opinion' or in the courts, the decisions of which administrators knew little.

86 No Condition, ch. 2.

87 See Brett L. Shadle, 'I will marry whom I want: marriage, adultery and elopement in colonial Gusiiland, Kenya', paper presented to American Historical Association annual conference, Jan. I998; Kenda Mutongi, "“Worries of the heart": widowed mothers, daughters and masculinities in Maragoli, Western Kenya, I940-60', Fournal of African History, 40 (1999), 67-86. 